\title{
High-resolution MRI of radiation-induced intracranial vasculopathy
}

Figure MRI, CT angiography, and high-resolution MRI findings of the patient

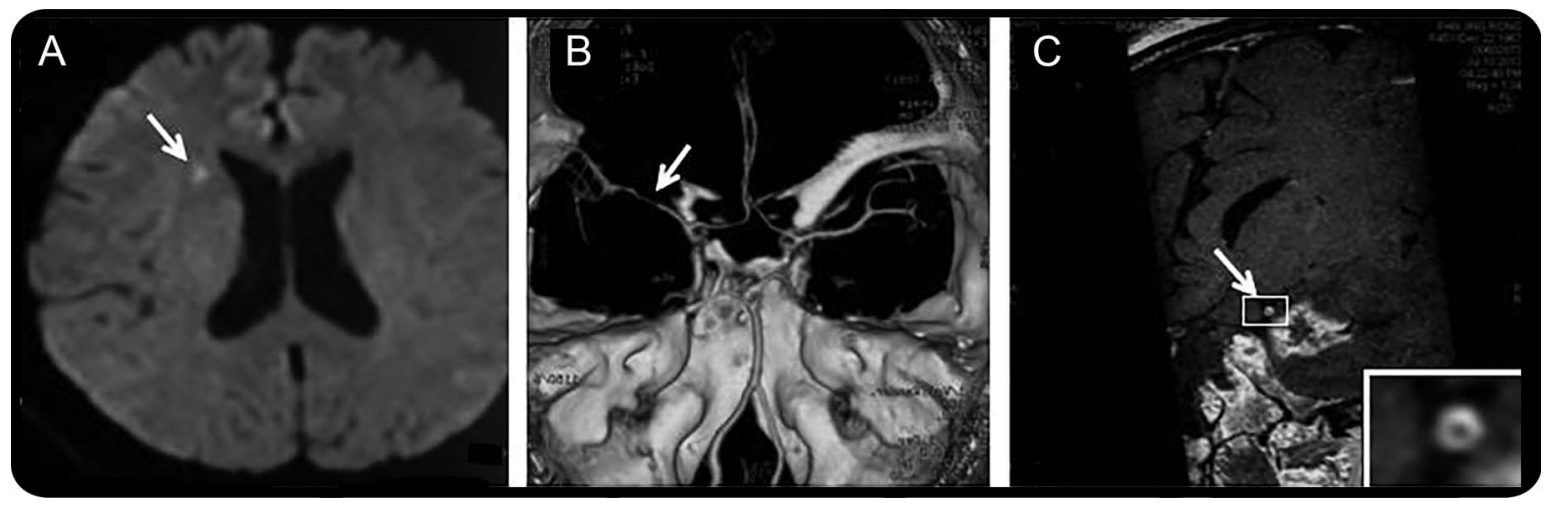

(A) Brain MRI shows an acute lesion within the anterior periventricular white matter (arrow). (B) CT angiography shows right middle cerebral artery stenosis (arrow). (C) On T1-weighted contrast-enhanced high-resolution MRI, a concentric vessel wall enhancement is revealed (arrow, and on the magnified image).

A 46-year-old woman without traditional stroke risk factors presented with acute left limbs numbness. Two years prior, she had a right cranio-orbital junction meningioma resected and received radiation therapy (target dose DT 60 Gy/30 F, 5 F/W, 2 Gy/F). MRI revealed a diffusion-positive focus within the anterior periventricular white matter. CT angiography showed $>50 \%$ right middle cerebral artery (MCA) stenosis. Highresolution MRI (HRMRI) suggested concentric vessel wall thickening with contrast enhancement (figure).

The precise mechanism of radiation-induced intracranial large vessel arteriopathy is not understood. Although radiation is more commonly associated with arteritis, radiation may contribute to carotid atherosclerosis and stenosis. ${ }^{1}$ In our patient, the features of MCA wall lesions on HRMRI are consistent with cerebral vasculitis. $^{2}$

Min Li, MD, Shi-Wen Wu, MD, Wei-Hai Xu, MD

From the General Hospital of Chinese Armed Police Forces (M.L., S.-W.W.); and the Peking Union Medical College Hospital (W.-H.X.), Chinese Academy of Medical Sciences, Beijing, China.

Author contributions: Min Li: drafting the manuscript. Shi-Wen Wu: design, conceptualization of the study, analysis and interpretation of the data, drafting and revising the manuscript. Wei-Hai Xu: design, conceptualization of the study, analysis and interpretation of the data, drafting and revising the manuscript.

Study funding: No targeted funding reported.

Disclosure: The authors report no disclosures relevant to the manuscript. Go to Neurology.org for full disclosures.

Correspondence to Dr. Wu: neurowu@gmail.com or Dr.Xu: xuwh@pumch.cn

1. Gujral DM, Chahal N, Senior R, Harrington KJ, Nutting CM. Radiation-induced carotid artery atherosclerosis. Radiother Oncol 2014;110:31-38.

2. Swartz RH, Bhuta SS, Farb RI, et al. Intracranial arterial wall imaging using high-resolution 3-Tesla contrast-enhanced MRI. Neurology 2009;72:627-634. 


\section{Neurology}

\section{High-resolution MRI of radiation-induced intracranial vasculopathy \\ Min Li, Shi-Wen Wu and Wei-Hai Xu \\ Neurology 2015;84;631 \\ DOI 10.1212/WNL.0000000000001223}

\section{This information is current as of February 9, 2015}

Updated Information \& Services

References

Subspecialty Collections

Permissions \& Licensing

Reprints including high resolution figures, can be found at: http://n.neurology.org/content/84/6/631.full

This article cites 2 articles, 1 of which you can access for free at: http://n.neurology.org/content/84/6/631.full\#ref-list-1

This article, along with others on similar topics, appears in the following collection(s):

All Cerebrovascular disease/Stroke

http://n.neurology.org/cgi/collection/all_cerebrovascular_disease_strok

All Clinical Neurology

http://n.neurology.org/cgi/collection/all_clinical_neurology

Fungal infections

http://n.neurology.org/cgi/collection/fungal_infections

Information about reproducing this article in parts (figures,tables) or in its entirety can be found online at:

http://www.neurology.org/about/about_the_journal\#permissions

Information about ordering reprints can be found online:

http://n.neurology.org/subscribers/advertise

Neurology ${ }^{\circledR}$ is the official journal of the American Academy of Neurology. Published continuously since 1951 , it is now a weekly with 48 issues per year. Copyright @ 2015 American Academy of Neurology. All rights reserved. Print ISSN: 0028-3878. Online ISSN: 1526-632X.

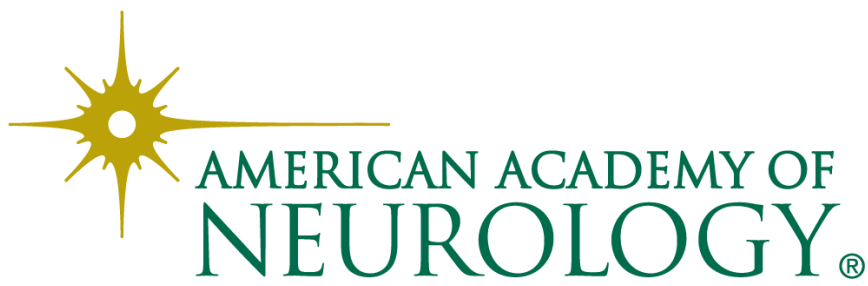

